\title{
NEW HORIZONS IN THE LAW OF THE SEA
}

David Leary and Anshuman Chakraborty*

This article summarises the proceedings of the symposium held at Victoria University of Wellington in September 2004 to mark the tenth anniversary of the United Nations Convention on the Law of the Sea.

The authors highlight the key themes of the symposium, basing their discussion on the five topics of maritime security, enforcement and compliance in fisheries law, Pacific regional issues, dispute resolution and the law of the sea, and future directions for the law of the sea.

On the tenth anniversary of the entry into force of the 1982 United Nations Convention on the Law of the Sea (UNCLOS), ${ }^{1}$ it is appropriate to take stock of where the law of the sea is heading. The negotiation and entry into force of UNCLOS was an enormous achievement and it now forms the basis of global and regional oceans governance. The past 10 years have seen many important developments in oceans management, as well as the emergence of new issues unforseen by the drafters of the Convention.

To mark the tenth anniversary of the entry into force of UNCLOS, academics and interested parties from Australia and New Zealand met at Victoria University of Wellington on 4 September 2004 to discuss current problems affecting the law of the sea, as well as to identify potential avenues for future development of the law.

Papers were presented by leading academics from Australia and New Zealand. Following on from these papers there was considerable discussion by participants. Four main themes were explored at the symposium: maritime security; enforcement and compliance in fisheries law; regional issues associated with the Pacific; and dispute resolution. The presenters discussing maritime security were Professor Stuart Kaye, Professor Scott Davidson and Professor Campbell

* David Leary and Anshuman Chakraborty were the nominated rapporteurs for the Symposium. David Leary's attendance at the Symposium was made possible with assistance from an endowment by Judge Ian Borrin. Anshuman Chakraborty is a current LLM student at Victoria University of Wellington Law Faculty.

1 United Nations Convention on the Law of the Sea (10 December 1982) 1833 UNTS 3. The Convention entered into force on 16 November 1994. 
McLachlan (commentator). Enforcement and compliance in fisheries law was discussed by Ms Joanna Mossop, Ms Rachel Baird, Professor Alexander Gillespie and Mr Stan Crothers (commentator). The presenters for the third session, issues in the Pacific Region, were Dr Laurence Cordonnery, Mr Bruce Chapman and Mr Michael Powles (commentator). Associate Professor Rosemary Rayfuse and Mr Andrew Serdy discussed dispute resolution in the law of the sea. The final session of the day, chaired by Mr Bill Mansfield and Professor Don Rothwell, drew together many of the themes raised during the day and provided a further opportunity for discussion by participants. The following report provides an overview of some of the main concerns that emerged from papers presented at the symposium and subsequent discussion.

\section{MARITIME SECURITY: EXPLORING THE BOUNDARIES OF THE LAW OF THE SEA}

Security issues have come to dominate the policy agenda globally and this trend is just as evident in the oceans. A core challenge for the future of the law of the sea will be managing the relationship between maritime security and the existing norms of international law. In terms of maritime security, discussion centred on two core issues: the Proliferation Security Initiative (PSI) and security-related problems associated with the various jurisdictional zones recognised by UNCLOS.

Professor Stuart Kaye, in his presentation, explored the origins and nature of the PSI in depth. ${ }^{2}$ $\mathrm{He}$ also examined the experience with the PSI to date. One of the main themes that emerged from this paper and subsequent discussion was the extent to which existing international legal principles can be used to justify the PSI. For example, does the PSI merely represent an extension of the controversial and often disputed principle of anticipatory self defence? No clear answer to this issue emerged from the discussion among participants but it was recognised that the main problem with this idea is that the use of force itself is prohibited by the United Nations Charter. Could the PSI be justified by the doctrine of necessity? PSI states seem to hold the view that the PSI should not be justified by the doctrine of necessity as this would be akin to admitting that the act of boarding a ship was illegal in the first place. Another significant concern expressed in relation to the PSI was its potential implications for navigational freedoms on the high seas, and for innocent passage in the territorial sea and archipelagic waters.

Similarly is there any overlap between existing laws dealing with piracy and new initiatives to deal with terrorism? This is unclear. Under international law piracy is narrowly defined. Thus under article 101 of UNCLOS piracy essentially involves any illegal acts of violence, detention, or act of depredation committed for private ends by the crew or passengers of a private ship or aircraft against another vessel. Arguably terrorism is done for political ends, not private ends, and therefore does not fall within the definition of piracy under international law. Should the law of the sea be

2 See "The Proliferation Security Initiative" <http://usinfo.state.gov> (last accessed 3 November 2005). 
revised to include political ends within the definition of piracy? Alternately what scope is there for further developments with respect to the implementation of the 1988 Convention for the Suppression of Unlawful Acts Against the Safety of Maritime Navigation (SUA Convention), ${ }^{3}$ which arose out of the Achille Lauro incident? ${ }^{4}$

The operation of the PSI also raises questions as to whether similar principles could be invoked in dealing with the problem of illegal fishing, linked as it is to the issue of flags of convenience. In future could we see like-minded environmentally conscious states boarding vessels which are believed to be engaged in unlawful fishing practices on the high seas?

While developments such as the PSI present new challenges to the law of the sea, other problems stem from the uncertainty of existing international law. Disputes still exist with respect to the scope of rights of innocent passage by vessels through the territorial sea, passage through straights used for international navigation and archipelagic sea lane passage. Many of the problems associated with these questions stem from either the failure of UNCLOS to adequately resolve these issues or from the fact that some states are not prepared to accept the compromises negotiated during the formulation of UNCLOS. As such, to what extent is there ever going to be scope for these issues to be resolved?

\section{ENFORCEMENT AND COMPLIANCE IN FISHERIES LAW}

Like maritime security, enforcement and compliance in fisheries law is a major challenge for international law now and into the future. Most unsustainable fisheries occur within the exclusive economic zone (EEZ) and as such the key focus for enforcement remains within EEZs.

Barriers to compliance are an important issue related to international fisheries management. A distinction needs to be made between states who wilfully do not comply with their international obligations and states who are willing but unable to comply. Achieving compliance by the latter is a question of capacity. These issues also raise questions as to the need to make a link between conservation measures and trade and economic factors, one of the most significant being the question of subsidies. There is also a need to extend catch documentation regimes to all parts of the market and not just up until the border of the importing state.

Concern was also expressed about the delinquency of flag states. Are we reaching a stage in international law with respect to illegal unregulated and unreported fishing where states which are delinquent in fulfilling their flag state obligations might lose the sovereign right to control their

3 Convention for the Suppression of Unlawful Acts Against the Safety of Maritime Navigation (10 March 1988) 27 ILM 672.

4 In October 2005 states concluded negotiations for an amendment to the SUA Convention expanding the scope of offences to include various terrorist activities and establishing a process to facilitate the boarding of vessels suspected of carrying weapons destined for use by terrorists. For further information, see < http://imo.org > (last accessed 20 November 2005). 
vessels, in much the same way as states that permit human rights violations may be subject to humanitarian intervention and thereby lose the right to control territory?

Questions also need to be considered as to the extent to which the overexploitation of fishery resources is driven by the motivations of the ultimate beneficial owners of the vessels. Would it be more effective to target measures against the ultimate beneficial owners of vessels rather than just towards the flag of convenience state? Alternately is the key problem the issue of overcapacity of fishing vessels rather than the absence of legal regulation?

Similarly might not efforts expended towards attaining sustainability be better served if they were designed to target the end user or consumer of fisheries resources? This suggests a role for education and market mechanisms in sustainable oceans governance.

While discussion with respect to overexploitation highlighted many problems, one significant emerging opportunity for fostering global oceans governance was noted, namely the growing international interest in the potential of high seas marine protected areas. There is currently some support for a network of representative marine protected areas in the high seas. Where there is political will to advance such ideas then regional organisations such as regional fisheries management organisations (RFMOs) may prove instrumental in this process, particularly with respect to fisheries issues.

\section{PACIFIC REGIONAL ISSUES}

To a large extent UNCLOS is a framework treaty which contemplates implementation of general obligations at the regional level. This is evident in recent developments in the Pacific region.

The Pacific region is the first region in the world to adopt a regional oceans policy. The processes leading up to its development and the issues dealt with in the policy were discussed in the third session of the symposium.

Despite the implementation of a regional oceans policy and the ongoing work of regional fisheries organisations, a large amount of work still needs to be done on developing appropriate legal and policy regimes for sustainable management of the regional marine environment in the Pacific.

A number of issues were canvassed in this discussion including:

- the need for greater recognition of customary law and practices and their integration into marine environmental management regimes;

- development of laws dealing with exploitation of marine genetic resources. Few if any of the small island states in the region have developed regimes dealing with bioprospecting and access and benefit sharing in relation to marine genetic resources; 
- similarly in many Pacific countries much work still has to be done in introducing legislation to provide for environmental impact assessment. In many respects this is symptomatic of broader problems of capacity and the lack of resources to implement and enforce laws in the marine environment throughout the Pacific region; and

- in part some of these problems can be addressed at a regional level through the development of guidelines for oceans governance and through regional capacity building exercises. One obvious area for further work in this regard is the need to elaborate detailed guidelines for the development and management of a network of regional marine protected areas.

In dealing with these and many other issues confronting the Pacific region it is clear that regional fisheries management organisations (RFMOs) will continue to have a prominent role to play. If this is the case then perhaps it is timely to assess the effectiveness of some of these RFMOs in fulfilling their mandate to date. It may be appropriate therefore for future research to consider the extent to which there is a need for structural reform with respect to RFMOs and other regional organisations such as the South Pacific Applied Geosciences Commission and the South Pacific Regional Environment Programme. This review process might also involve considering new ideas such as the potential for a regional oceans ombudsman.

As part of this assessment it would also appear appropriate that closer attention be paid to the relationship between such bodies and the work of trade bodies such as the World Trade Organisation. But the consideration of trade issues in regional oceans governance should not overlook the importance of the behaviour of end users of ocean resources. Harmful fishing practices such as reef fishing for tropical fish species using cyanide and catching sharks are driven by market demand for such resources, as well as cultural forces. Until market demand and cultural practices are adequately recognised in law and policy regimes it will be difficult to address these issues even on a regional level.

\section{DISPUTE RESOLUTION AND THE LAW OF THE SEA}

One of the major achievements of UNCLOS often referred to is the inclusion of significant provisions dealing with dispute resolution and in particular the creation of the International Tribunal on the Law of the Sea (ITLOS). The final formal session of the symposium was devoted to considering the effectiveness of dispute resolution mechanisms under UNCLOS.

A paper by Associate Professor Rosemary Rayfuse, reproduced later in this volume, laid the foundation for robust debate on this issue. Following this paper, discussion highlighted that opinion was divided as to the success or failure of the ITLOS as a forum for dispute resolution. The contribution of ITLOS to the development of jurisprudence in relation to the law of the sea was also canvassed. 
But while criticisms of ITLOS are many, it was nonetheless recognised that the dispute resolution mechanisms under UNCLOS clearly represent one of its major achievements. It was also recognised that only a decade after UNCLOS entered into force and eight years since the operation of ITLOS, it was perhaps too early to make definitive comments about their success or failure.

\section{FUTURE DIRECTIONS}

One of the clearest areas of concern that arose from discussion at the symposium was the relationship between the law of the sea and new developments in maritime security. There are inherent tensions between rights recognised by UNCLOS and new developments such as the PSI. Will the law of the sea processes be robust enough to resolve these tensions? We need to be mindful of these tensions because of the risk that the entire package negotiated in UNCLOS might become unravelled, with very serious consequences for the rule of law in the oceans. UNCLOS was after all the result of a very long and complex diplomatic negotiation process. Although it is not a perfect constitution for the oceans, it is a constitution nonetheless and there would be serious consequences for the rule of law in the oceans should it break down.

Twenty five years after the adoption of UNCLOS it is easy to forget the situation of near anarchy in the oceans prior to UNCLOS and that, in order to achieve UNCLOS, compromises and ambiguities were necessary, and the range of issues that had been resolved is a package. Therefore supporting UNCLOS as it stands should be a prime policy objective. If we abandoned UNCLOS it would risk creating a case of anarchy where actions are determined by power rather than rules. We also need greater emphasis on making use of processes such as the United Nations Informal Consultative Process on the Law of the Sea to help identify weaknesses and to build consensus on the need for change. ${ }^{5}$

There also needs to be a greater linkage between previously discrete but parallel bodies of international law as it applies to the oceans. We experience parallelism in a whole range of areas including the law of the sea, international environmental law, international trade law and human rights. Regimes have been compartmentalised but clear significant crossovers have emerged and thus there is need for greater integration. The biggest challenge that multi-unilateralism throws up is how it affects multilateral aspects outside its frameworks. Instruments that might evolve within a region may be contrary to the whole package deal that evolved during UNCLOS. This suggests a need for greater development of regional oceans policies, in much the same way as is currently being developed in Australia. For example in the Asia-Pacific region there may be scope to develop a regional policy. Beyond that perhaps consideration also needs to be given to the development of a global oceans policy.

5 UNGA Resolution 33 (54) (18 January 2000). 
The research agenda into the future therefore needs to focus on the interaction between discrete areas of law and, beyond that, towards a greater understanding of the interaction between law, policy and science. One research agenda that may interest researchers from New Zealand is the Australia Canada Oceans Research Network (ACORN). Perhaps the possibility of participation by New Zealand academics in ACORN work could be considered. One of the significant benefits of the ACORN work is the interdisciplinary nature of the research which includes social scientists, lawyers, and biologists. There are a number of potential areas in which scholars and government officials could join in the next phase of its work.

We could also consider the need for annual discussions among New Zealand, Australia and other Pacific nations to explore ways to identify and deal with the major issues. These discussions might produce suggestions on many burning issues such as overfishing and land based pollution, which we could take to the world as a region.

Thus, although we can look back and be proud of what was achieved with the negotiation and entry into force of UNCLOS and subsequent developments under its framework, there is still much to be done in further developing the law of the sea as well as responding to new challenges. All of these issues will no doubt provide fertile ground for research and development of law and policy in the oceans well into the future. 
